\title{
MAINSTREAMING IDEA: ALTERNATIVE READING OF STATE AND CIVIL SOCIETY RELATION IN POLICY MAKING
}

\author{
Cahyo Seftyono ${ }^{1,2}$ \\ Purwo Santoso ${ }^{2}$ \\ Muhadiir Muhammad Darwin ${ }^{2}$ \\ Agus Heruanto Hadna ${ }^{2}$ \\ ${ }^{1}$ Universitas Negeri Semarang \\ Sekaran, Gunung Pati, Semarang City, Central Java, Indonesia \\ ${ }^{2}$ Universitas Gadjah Mada \\ Bulaksumur, Sagan, Sleman Regency, Yogyakarta, Indonesia \\ Correspondence Email: cahyo.seftyono@mail.unnes.ac.id
}

Submitted: January 02, 2020, Reviewed: April 14, 2020, Accepted: Mei 02, 2020.

\begin{abstract}
Scientific climate as the unity of ideas and the activator of an organization is suspected to be a form of civil society leadership. It moves from the personification of actors to the debate of ideas. Civil society as a political movement is a study that still being debated because of its position when faced with the state and policy. This article provides a different review, by carrying out the phenomenon of research-based policy in Indonesia. Through qualitative data tracking, it was shown that some civil society did not put themselves in these two positions, namely as the opponent or the partner for the government. Furthermore, the reality showed that both of them, in this case civil society and the state were more concerned with the realization of their ideas, the openness, and the professionalism of publications to support policy making. More specifically, the existence of openness and implementation of science and information as a collaborative arena appeared from the interaction of the National Development Planning Agency and Knowledge Sector Initiative which had been running since 2011 in building the ecosystem of Research- Based Policy. Then, it was followed by the presence of Open Science community in 2017 and the establishment of National Research and Innovation Agency in 2019. Therefore, both collaborations encouraged the creation of a data openness climate in policy making. This was a general 'norm', but it did not work fully. Therefore, this article provides a space that the opportunities to strengthen the ecosystem of research-based policy can be optimized by setting out the idea approach and makes the civil society goes beyond the institutional barrier.
\end{abstract}

Keywords: Leadership; Civil Society; Political Actor; Idea

\begin{abstract}
ABSTRAK
Iklim ilmiah sebagai kesatuan gagasan dan penggerak suatu organisasi ditengarai sebagai bentuk kepemimpinan dalam masyarakat sipil. Ia bergerak dari personifikasi aktor ke perdebatan gagasan. Masyarakat sipil sebagai gerakan politik adalah studi yang masih diperdebatkan karena posisinya dalam kaitan dengan negara dan kebijakan. Artikel ini memberikan ulasan berbeda, dengan menjalankan fenomena kebijakan berbasis penelitian di Indonesia. Melalui pelacakan data kualitatif, ditunjukkan bahwa beberapa masyarakat sipil tidak menempatkan diri mereka di dua posisi ini, yaitu sebagai lawan atau mitra bagi pemerintah. Lebih jauh, kenyataan menunjukkan bahwa mereka berdua, dalam hal ini masyarakat sipil dan negara lebih mementingkan realisasi ide-ide mereka, keterbukaan, dan profesionalisme publikasi untuk mendukung pembuatan kebijakan. Lebih khusus lagi, keberadaan keterbukaan dan implementasi ilmu pengetahuan dan informasi sebagai arena kolaborasi muncul dari interaksi Badan Perencanaan Pembangunan Nasional dan Knowledge Sector Initiative (KSI) yang telah berjalan sejak 2011 dalam membangun ekosistem Kebijakan Berbasis Riset. Kemudian, diikuti oleh kehadiran komunitas Sains Terbuka pada tahun 2017 dan pembentukan Badan Penelitian dan Inovasi Nasional pada tahun 2019. Oleh karena itu, kedua
\end{abstract}


Vol.6, No.1, 2020

Doi: https://doi.org/10.24198/cosmogov.v6i1.25474

http://jurnal.unpad.ac.id/cosmogov/index

kolaborasi membuat penciptaan iklim keterbukaan data dalam pembuatan kebijakan. Ini adalah 'norma' umum, tetapi belum berfungsi sepenuhnya. Oleh karenanya, artikel ini memberikan ruang bahwa peluang untuk memperkuat ekosistem kebijakan berbasis penelitian dapat dioptimalkan dengan menetapkan pendekatan ide dan membuat masyarakat sipil melampaui sekat kelembagaan.

Kata Kunci: Kepemimpinan, Masyarakat Sipil, Aktor Politik, Ide

\section{BACKGROUND}

Indeed, research has been identified as a foundation in improving the welfare of the nation (RistekBRIN, 2020). However, based on the analysis issued by The Conversation (November 6, 2019) which related to the relationship between policy and academic world in Indonesia, it was stated that actually what had been the policy process in Indonesia so far was not in line with the quality of research as well as academic freedom. Furthermore, the last thing that we can perhaps refer to is what happens in the context of the dominance of policy makers and research funders because it rarely appears that the research is considered neutral and able to provide a full description of reality. For example, a survey institution even its core business is electoral, actually also provides other survey data (Puskapol UI, 2014).

Another more crucial issue is research quality in which is closely related to the idea of Research-Based Policy. Research-based policy necessitates the existence of Research and Development in each ministry which is supported by various research and survey institutions as well as universities (higher education). However, their research is not completely accessed and able to be tested for their quality. Even so with research in higher education, although there is a trend of opening access to research, yet so far the dissemination of research results in Indonesia has not been optimal Asmad et al. (2018).

The discourse about the idea of policy change actually is not a new thing. Specifically, Beland (2009) explains that policy change is not only a matter of institutional interaction but also is substantially a discourse of ideas. There is a dialogue between policy makers at the government level, the general public (commonly called civil society), and the transnational actors. The result of this struggle of ideas then influences and moves the policy that will be taken in an issue.

On the other hand, with regard to influencing and mobilizing ideas or policy, there is a study of leadership as the impact of the disruption era. Today, the boundaries of institutions and actors are blurred. The movement can also be in the form of interaction of ideas which do not require a formal leader, yet it just requires the originator of the idea. When everyone agrees upon an idea, then this desired idea can be realized. This is the opposite of autopilot management as an extreme point of governing without government which is sometimes misunderstood. The existence of too dominant 'governance' in non-state actors causes the state to have no role in the implementation of policy (Mayntz, 2017; Rhodes, 1996). 
Vol.6, No.1, 2020

Doi: https://doi.org/10.24198/cosmogov.v6il.25474

http://jurnal.unpad.ac.id/cosmogov/index

This research examines the existence of Knowledge Sector Initiative (KSI) and Open Science Community (Irawan, 2017; Kiramang, 2019; KSI, 2020; Tim Sains Terbuka, 2020) which becomes a preliminary study. Both represent the openness movement and the real use of science. Moreover, they have focus on strengthening literacy which based on scientific research and publishing both inside and outside the university to support research transparency and practically support policy.

More substantively, what is being fought for by the non-state community is also what the government wants to strive for together, related to scientific publication and its application to policy making. This can be seen from what is delivered by each element as well as a written policy made by the government. Thus, policy reading is more as a discourse of ideas in the public sphere compared with the contestation of actors in the civil society, the state, and the market/private. This article will elaborate that policy actually does not merely arise from the relationship between civil society and the state (Bennett et al., 2019). Rather, beyond that actually, there is a more important thing and moving both, namely the same idea in designing policy.

\section{METHOD}

The research method used in writing this article was by analyzing the literature which was strengthened by interviews, documents, and other sources that can be accessed openly. The official information gained from Open Science Community, KSI, the National Development Planning Agency
(Bappenas), and National Research and Innovation Agency (RistekBRIN) were elaborated through civil society literature and leadership. Both of these discussions were a meeting point for the study of new civil society and its position in political relations with the state and the market/private sector. The analysis in writing this article was strengthened by reading the official publication of KSI (KSI, 2020) and the Open Science Community.

While other findings which are based on other sources and can be accessed their basis are website information, activists and community statements or discussions on social media (the Open Science Community, KSI, National Development Planning Agency, RistekBRIN) as well as other relevant information on their movements in strengthening literacy and their impact on policy. Likewise, the findings that become representative of the state and the market/private sector, both of them at this stage are still based on the official information released by National Development Planning Agency, National Research and Innovation Agency and related institutions.

Explorative qualitative research was conducted to answer these questions, first how the public sphere upon the policy raised through the interaction of KSI and the Open Science Community as civil society with other stakeholders in supporting the ecosystem of open research based-policy more specifically from the key actors (Kindon, Pain, \& Kesby, 2007; Ritchie, Lewis, Nicholls, \& Ormston, 2013). Second, how is the collaboration as well as constructive criticism towards the 
Vol.6, No.1, 2020

Doi: https://doi.org/10.24198/cosmogov.v6i1.25474

http://jurnal.unpad.ac.id/cosmogov/index

government to improve the quality of policy in Indonesia. This was used to strengthen the literature discourse on changes in the patterns of interaction of civil society in policy making.

The results of reading the official references of institution confirmed by interviews or elaboration through secondary sources from the literature regarding leadership that still became the central actor (Wang, 2018) and the relationship between the state and civil society (Brandsen, Trommel, \& Verschuere, 2017).

\section{RESULT AND DISCUSSION} The Relation of the Idea of Leadership

So far, the leadership studies which have emerged explain manager-employee relations (Knouse \& Carson, 1993; Taylor, 2004) until transformative leadership (Rosenberg, 2010) which place the leaders as a servant of their members (van Dierendonck, 2011). Therefore, a red line can be drawn that all the time, leadership has been studied in managerial issues and tended to study of actors. Whereas in the digital era, each actor no longer needs to meet intensively, ideas can emerge from all directions and does not focus on one particular actor. Therefore, making the actor as a central element in the leadership issues is something that needs to be reviewed.

As noted by Gurdjian et al. (2014), understanding the difference between developing leaders and developing leadership is an important thing. Leader development focuses on developing an individual leader or an actor while leadership development focuses on the development process that inherently involves many individuals (for example Leader and followers or among colleagues in self-managed work team). Developing an individual leader/actor and developing an effective leadership process involves more than just deciding which leadership approach will be used to motivate effective development. This is because human development involves a complex set of processes.

Consequently, civil society and leadership still become study of actors so that the leadership is generally described as a part of the corporation and training for the development of civil society. Furthermore, deeply the study of civil society is identical to the development of a country, in this case, a country that is classified as more advanced to the poor or developing countries, including organizations or corporations in it (Cosgrove, 2010; Keohane, 2014).

For example, the relations between government, market/private sector, and the academic community in Indonesia are influenced by leadership culture which has begun to shift in the disruption era. The internet and digital era make it possible for policy makers do not have to meet face to face, yet those who interact more quickly are their ideas (Margetts, John, Hale, \& Reissfelder, 2015). Then, what actually emerges as a policy is that besides being relation in the public sphere, also being one of the signs that currently the tie between actors is also dominated by non-actor tie. Consequently, there are non-actor aspects such as value, idea, technology, and so on. These aspects work dynamically and cause 
Vol.6, No.1, 2020

Doi: https://doi.org/10.24198/cosmogov.v6i1.25474

http://jurnal.unpad.ac.id/cosmogov/index

the status of actors no longer become to dominant as a separator.

In addition, Gardner et al. (2020) by referring to the publication in The
Leadership Forum for the period 19902019 map out several leadership issues that are important to be examined in the future as a response to the existing discourse.

Table 1. The Map of Leadership Study

\begin{tabular}{ccc}
\hline No & Issue & Level of Study \\
\hline 1 & Strategic Leadership & Frequent enough to be studied \\
2 & Analysis Level & Frequent to be studied \\
3 & Leadership development and leadership system & Seldom to be studied \\
4 & Leadership Context & Frequent enough to be studied \\
5 & Women's Leadership & Seldom to be studied \\
6 & International Leadership & Seldom to be studied \\
7 & Technology (Role in Leadership) & Seldom to be studied \\
8 & Transformative Leadership/Charismatic & Frequent to be studied \\
\hline
\end{tabular}

Resource: Gardner et al. (2020)

The map made by Gardner et al. is in line with the increase in the discourse on disruptive leadership. Based on the idea of disruptive leadership that is currently dynamic, it can be said that what becomes a point in contemporary leadership is no longer on the actor (points 4 and 7), but on the ability to see and solve the problems. The point of the idea in an organization used to respond to the problems even becomes more important in observing the current organization. The organization is nevermore identic with the actor who leads, but the ideas which are in the form of values and norms that move them. In addition, Yorkovich wrote about disruptive leadership in response to the idea of disruptive innovation from Clayton Christensen (Bower, Joseph B.; Christensen, 1995). Disruptive leadership is described as seeing the problem in a new way, finding opportunity in the problem which cannot be resolved, accepting failure, having patience for change, and hoping quickly to have a meaningful impact.

On the other hand, Komives and Wagner (2016) also highlighted the power of environment and organization which had shaped their leadership and development. They illustrated the similarities and the defining characteristics of leadership theory compared to other leadership perspectives (example: transformational, charismatic, servant and spiritual leaderships). In this tone, a model of the relationship between authentic leadership, follower development, and follower performance was presented (Avolio \& Gardner, 2005). The proposed model highlighted the process of developing self-awareness and selfregulation of leaders and followers, as well as the influence of leaders' and followers' personal histories on authentic leadership and followers. 
Vol.6, No.1, 2020

Doi: https://doi.org/10.24198/cosmogov.v6i1.25474 http://jurnal.unpad.ac.id/cosmogov/index

This leadership issue then becomes an important study when there is a shift in leadership patterns that moves from the role of actors to the interaction of ideas, and the collaborative action. For example, Sutherland (2013) criticized the actor-based leadership model by proposing criticism based on anarchism. He placed everyone in the same position and must be involved in the organization in a participatory manner. The discourse that related to ideology, identity, and meaning of leadership more influenced the leadership of an organization than those who lead the organization itself. Nowadays, the hierarchical approach is no longer dominant and more inclined towards equal collaboration, although in the manner of institutions, there are actors which have more authority. This is in line with Raelin (2016) and Crevani et al. (2010) who said that leadership is a matter of practice and interaction. Moreover, it can even be said that leadership can run without a leader, but with collective agencies.

In addition, the leadership besides has experienced a shift from the actor to an idea, it is also related to strong or not an idea is submitted. Interaction occurs in the public sphere, especially about what is considered important and then becomes a joint discourse as well as things that may be considered important only by some elements so that it becomes their own interests.

When these ideas intersect and reinforce each other among all elements, then this is part of a form of encouragement for each of them to carry out the same interests. However, something that is being an important part is whether the idea is indeed from the beginning is shared or inspires each other. When it inspires and becomes a shared idea, that's when leadership actually shifts from the actor to the idea. It doesn't matter who owns the idea, yet what is more important is that what is expressed is a shared idea. If it is related to the relationship of National Development Planning Agency-KSI and National Research and Innovation AgencyOpen Science Community, then this provides an opportunity that with the leadership, the idea of 'scientific openness for academics and policy will be the formula for making more effective policy process and there will be no party feels more authoritative for the common interest (Sains Terbuka Tweet, 2019).

\section{Civil Society and the State}

In general, the description of civil society is the adoption of a liberal society that places the relationship between civil society and the state as well as the market/private sector. In addition, Klein and Lee (2019) analyzed at least three patterns that related to this relationship. It was stated (Scheme 1) that the interaction of civil society with the state and the market/private sector: the first pattern is identified as politics of influence. Civil society is not related to the state or the market/private sector, yet it stands alone as an independent entity. Civil society towards both the state and the market/private sector is distant and gives reactions whether supporting or rejecting. Vice versa, the state and the market/private sector give the same reaction to civil society.

The second pattern is identified as a politics of substitution. There is a view that civil society, the state, and the 
Vol.6, No.1, 2020

Doi: https://doi.org/10.24198/cosmogov.v6i1.25474

http://jurnal.unpad.ac.id/cosmogov/index

market/private sector are often related to one another. The state can be a part of civil society. Sometimes civil society becomes a subordinated part of the state and vice versa. This is because between the state and civil society interact with the exact same values and become part of each other. For example, the existence of civil society in Indonesia involves in founding the country. The values certainly overlap, or conversely, the state creates civil society through the formation of an organization which then creates scientific and professional associations.

Scheme 1. Theorization of Civil Society

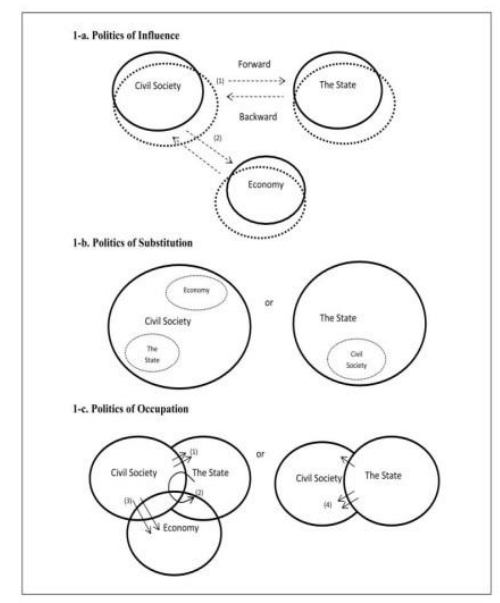

Klein and Lee (2019)

The third relation, a view related to the relationship between civil society, the state, and the market/private sector. In this view, they influence one another and partially dominate. At certain stages, the existence of civil society influences what is done by the state through their existence in the system, and vice versa. According to the context of a democratic country, this is indeed possible, especially if they look at each political power. Perhaps, there is an actor from the state that becomes the motor in civil society, civil society actor who is the part of the state, etc. However, the entry of civil society actors into the country (and vice versa) did not last long. There is a time limit caused by the democratic system in which the leadership in a democratic system must be limited. Generally, this limitation occurs in two election periods.

Moreover, the summary by Klein and Lee on the relation of civil society, the state, and the market/private sector assumes that the three as truly separate elements from each other, although they occasionally interact. In fact, it cannot be denied that the actors within the state may be part of the market/private sector or the part of civil society, etc. For example, this can be traced through the statements and policies made by each actor. Without having to be in one particular position, each actor can express ideas or ideas that intersect with other positions, while still carrying the agenda in the place occupied currently by the actor. 
Vol.6, No.1, 2020

Doi: https://doi.org/10.24198/cosmogov.v6i1.25474

http://jurnal.unpad.ac.id/cosmogov/index

\section{Civil Society: From Actor Interaction to the Discourse of Idea}

Nowadays, the development of politics and democracy brings out one of the most central discussions about the concept of civil society. The elements outside the state and the market/private sector have socio-political influence. Their existence is considered to be a solution to democratic problems. This is because of civil society that becomes a public representation in facing the state which has been legally and formally mandated to run people's power.

The presence of civil society which is in line with the strengthening of liberalism and democracy allows the creation of participation in the public sphere. The people originally have given their legitimacy to the state then have their ownership control back over the implementation of that legitimacy. In the process, there is a dialogue in the public sphere between the state and non-state (in this case civil society and the market/private sector) to determine the policy that will be taken by the government.

Civil society as part of liberal democracy does not give full power to the state to do the things it wants to do. Civil society, in this case, enables the public to be more actively involved in the existing policy processes. De Tocqueville (1982) states that civil society is a school of democracy that ultimately will shape a more dynamic democracy. With free associations, people have an attachment to the issues that directly touch them: life, freedom, and ownership.
By using Tocqueville's logic, then we can find that the stronger civil society in controlling the state, the better the existing democracy. This is an input to the public policy approach which has been dominant and it is related to the meaning of the statecentric policy. The policy is what is done or not (by the government). This view makes the government seem to be the only element in the policy process, in which essentially there are other elements that are also involved in the process. There is a discourse of ideas in making and implementing policy.

Basically, the discourse of the policy process itself is an interaction between the state and other elements in the public sphere. If it is examined further, this more dynamic public sphere cannot be separated from its birth at the end of the 17th century. The development of public sphere in the 18th century necessitated a strong, intense, and dynamic interaction. This is in line with what revealed by Habermas related to the network of actors in the European Industrial revolution era (Habermas, Lennox, \& Lennox, 1974; Hohendahl \& Silberman, 1979). The network of actors allows the emergence of dominant ideas at the local level then to be raised in the debate of the policy-making elite. A network of active actors makes it possible for the presence of democratic deliberation and in this context the spread of knowledge as a driver of the same understanding towards the policy between civil society and the state.

The elite which is identical to a leader of the group emerges as a consequence of the interaction between the owner of capital and the workers. The elite 
Vol.6, No.1, 2020

Doi: https://doi.org/10.24198/cosmogov.v6i1.25474 http://jurnal.unpad.ac.id/cosmogov/index

also opens up other pandora related what are the means used to strengthen the influence between them. Habermas brings the idea of bourgeois public sphere, space where only actors with certain resources will interact and strengthen each other in order to maintain their business in the public sphere (Habermas, 2010; Prasetyo, 2012). In other words, civil society becomes a public representation in accordance with their socio-political interests.

The interests shown up by civil society, besides those are the results of horizontal interaction between parts in the society they are also a response to the lack of government attention from the discussion upon the developing issues. In addition, due to keeping the resources, the need for broader interests needs to be expressed so that civil society becomes stronger and there will be also more supporters. As a result, their participation also becomes more dynamic in the policy that will be taken by the state. In this case, the participation is not merely by positioning themselves in opposition but can also act as a partner in supporting government policy.

Afterward, the dilemma in seeing the interactions between the state, civil society, and the market/private sector arises when civil society has been positioned as the opposition of the state and the market/private sector because of their formal existence. As a result, the acceptance of ideas that could be similar to the state (and market/private) would be immediately rejected due to the positioning of each. In fact, the existing reality allows space for the same ideas from each actor. In addition, the idea given by civil society as the policy will certainly give an impact on the public so that it needs to be appreciated. Then, if we considered the current context of civil society in Indonesia, it is possible to involve cross-actor involvement in the elements that participate in the public sphere. Therefore, there are multiple roles of each actor who interacts in public sphere, both physically and in the manner of ideas.

Nowadays, the more complex thing regarding civil society is the regional boundaries and the activities of each actor which cannot be insulated in one particular territory, including whom they are connected with. So, it means that the interests and the ideas possessed go beyond the more local or national interests as well as the interests that are being carried out. The stronger the network owned, the stronger the influence, and vice versa.

These completely informal and fluid activities make the participation of civil society in the policy process at the public sphere more dynamic. On the one hand, they can appear as local actors at the same time they actually are also international networks (Krawczyk, 2019). At one independent time, at the same time, they can also be the representative of the market/private sector as well as the state.

Basically, the public sphere policy which brings out the political elites also becomes an important part of the interaction process of community with the state. This includes market/private entities. With such conditions, therefore the implementation of the policy process requires leadership which can combine various interests. In addition, the leadership itself has been synonymous with the actor 
Vol.6, No.1, 2020

Doi: https://doi.org/10.24198/cosmogov.v6i1.25474

http://jurnal.unpad.ac.id/cosmogov/index

which can come from the state, the market/private sector or civil society.

\section{The Leadership of Civil Society Idea: Collective and Interactive Leadership}

In general, the idea of leadership is understood originating from managerial relations as well as servant. However, it gets challenges from certain phenomenon such as the public sphere which is now no longer completely physical interaction. Therefore, the existence of leadership discourse becomes important. The actors in leadership relation as presented in various literature are nevermore the central role because today they do not have to meet with each other to be able to work together. There is a work pattern that tends to think about the similarity of ideas rather than who is more authoritative in carrying out the ideas.

Nowadays, the leadership issues are more about finding the solution and not about how the relation of actors involved in a system. Indeed, the leader as an actor still exists, yet what becomes an important part of leadership is precisely how each actor is bound to one another with the same goal. Furthermore, it is more about how one actor influences other actors so that the system or the organization that is run together becomes active. In addition, leadership shifts from superior to subordinate then it becomes leadership with the characteristics of dialogues of ideas and dynamic interactions, which is also synonymous with disruptive leadership (Bower, Joseph B. and Christensen, 1995; Raelin, 2016).

Interactive and collaborative leadership allows the emergence of influence outside the actor who should have dominance in the system. Shared ideas as well as verified knowledge, which are carried across the boundaries of actor, make it possible to become driving actors across political structures, for the broader context such as the involvement of elements in joint issues or policies at the country level. There is also the involvement of civil society and the market/private sector which indirectly gives influence to the state/ the government. On the other hand, the state and also the market/private sector are not spontaneously separated from the dynamics that exist in civil society. Even so with the reality that is playing at the market/private sector or business level, in fact, they are also directly or indirectly involved in the actors that exist in the state and civil society.

The leadership context in the interactions of policymaking is therefore interesting to be studied because it involves the state, the market/private sector, and civil society. The three of them interact with each other to propose their respective interests in order to be accommodated by the policy to be taken so that it is legitimate. To avoid conflicts of interest which then cause the same and greater interests and to be ignored, these three elements must be able to be united in a common problemsolving idea. Three of them which all the time have been separate and prioritizing each other's own interests, need to unite their vision to find a way out of the existing problems to realize a joint policy.

Such a leadership model is more or less similar to the concept of transformative or serving leadership. It means that not only the state that has the authority and provides 
Vol.6, No.1, 2020

Doi: https://doi.org/10.24198/cosmogov.v6i1.25474

http://jurnal.unpad.ac.id/cosmogov/index

services to the public optimally but also how the market/private sector and civil society also provide services to others so that they do not force their interests to be achieved, but prioritize joint solutions. Transformative and serving leadership, in this case, is no longer merely about who serves whom but also what can be served by each actor.

With the demand for solving more complex problems as well as resources that are not collected in one actor, the need for collaboration becomes more urgent. The leadership which has been identical with power, then needs to be discussed again, considering the problem-solving in the democratic space is no longer thick with the top down color, but through the participatory idea. The participatory can be critical, rejection, or even support on the policy that will be taken and implemented together.

Besides, the participation as a form of relationship between the actors, another important thing also appears in the reality is that each actor also has a non-singular role. This is what then causes the leadership approach needs to be reread from who the powerful actors are and towards what they stand for because in one entity actor can also have a role which actually becomes the domain of other actors. For example, as part of civil society, at the same time, there are actors who are also the representative of the state and market/private sector or vice versa. Consequently, the existence of this multi-role causes the leadership issues do not be in the form of central actor, in this case in one role having power and at the same time he actually becomes the executor.
The policy of scientific publishing in Indonesia, it can be said that leadership is a reflection of the role of the actor who in the beginning is quite central in the country, then it becomes a diffused leadership. Even in some conditions, there are actors of government who are actively involved in assisting civil society. At the same time, civil society is actively involved in government programs, including the adoption of programs inspired by the activities of civil society.

The programs adopted by the government, as well as civil society and the market/private sector mutually, show that the actors cannot be separated from one another in policy making. In the relation between the Open Science Community and National Research and Innovation Agency, for example, they then come up with the policy which is more pro on the science openness and pre-print (RistekBRIN, 2020). While for the collaboration of KSI and National Development Planning Agency, in the last decade, both have produced a variety of working papers which influence the national policy, ranging from: research funding, bureaucratic reform, mental revolution, etc. (Knowledge Sector Initiative, 2020). Moreover, each of them complements each other. Therefore, the ideas owned by the actors that participate in the policy then can make them interact with each other both in the context of mutual support and mutual negation.

\section{The Openness of Publication and Research-Based Policy}

According to Dunlop (2012), an epistemic community arises when there is a 
Vol.6, No.1, 2020

Doi: https://doi.org/10.24198/cosmogov.v6i1.25474 http://jurnal.unpad.ac.id/cosmogov/index

group of people from diverse backgrounds gathering together. They have the same goal that is producing discourse and building narratives. They are also bound fluidly by the values that are struggled by themselves. This is in line with Cohendet et al. (2014) who reveal that where science is used in open spaces to produce new knowledge.

This new knowledge is reproduced continuously as an effort to defend what is believed and to be collective energy (Meyer \& Molyneux-Hodgson, 2010). The discourse related to the epistemic community is actually more concrete. The existence of an epistemic community is a part of the struggle in global discourse. How decision making (in this case the epistemic community) determine the interests of the state and formulate policy to deal with complex and technical issues.

The delivery of these issues turned up by the people who are experts in their fields to give confidence to the country in the struggle of ideas both in order to win the international political battle and to build cooperation. It means that the responsibility of an epistemic community is to convey ideas that become an internal interest. Not following the global will or running away from the battle of ideas.

Open Science is a community which consists of activists with various academic activities which in this study represent the epistemic community. Especially, with their involvement in promoting transparency of research to ensure that the independence of the researcher as author of the results of research and unnecessary taken by other parties (Tim Sains Terbuka, 2020; Webinar
Sains, 2019). In this case, something that becomes an important point in their struggle is the reasoning: "Good research is correct research." Furthermore, the right upon the idea and the work actually belongs to the researcher.

Based on the context of the exchange of ideas, through this repository, it appears that what is being an activity of open science activists is to fight the capitalization of ideas or knowledge by releasing work in an online repository. They hope that scientific discourse can be carried out more openly and fairly. Furthermore, the knowledge which has been disseminated will be able to reach all academic networks which in turn will strengthen literacy for all groups.

In addition, the openness of the results of research and publications in scientific discourse and the criticism of findings can be better (Aribowo, 2019; Irawan et.al., 2017). Besides academically causing the quality of scientific literacy to be weighted because it can be accessed and commented on by academics or other researchers, there is a more practical role in this issue of openness of knowledge. This is the emergence of open science activists from not only academics society but also from the society of other government institutions, such as the information commission and other researchers in the ministry (The Conversation, 2020; Ridlo, 2018).

In Indonesia, a partnership that is based on the unity of ideas of researchbased policy has emerged between the National Development Planning AgencyKSI (Pellini et. al, 2018). Their collaboration has emerged between the 
Vol.6, No.1, 2020

Doi: https://doi.org/10.24198/cosmogov.v6i1.25474

http://jurnal.unpad.ac.id/cosmogov/index

2011 period until now. Whereas, recently, by the emergence of the National Research and Innovation Agency (BRIN), the discourse of strengthening policy making based on innovation especially research and scientific publication also become more potential (Irawan, 2020). Including their collaboration by involving the Open Science Community as the input in encouraging transparency of publications so that the transparency in publications will make policy references more valid.

Scheme 2. The Map of Actors Relations in the Ecosystem of Research-Based Policy in Indonesia: Case for KSI-Bappenas-Open Science-RistekBRIN

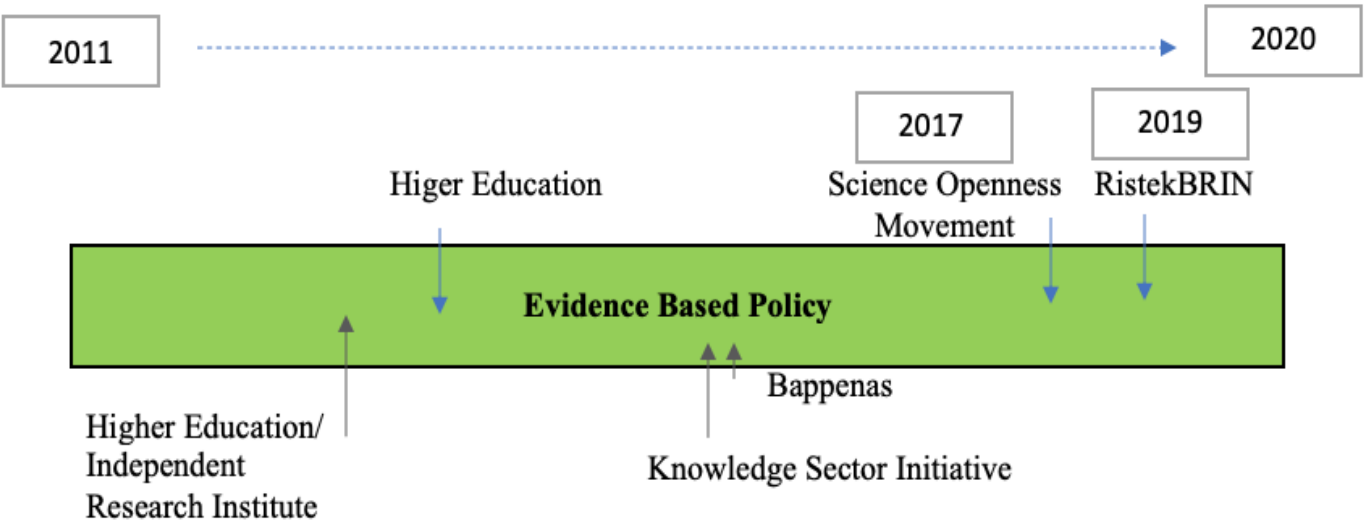

Source: Author Compilation

The discourse of the openness in information actually not only dealing with the internal domestic issues but also led to a movement on a larger scale: international. In the context of the National Development Planning Agency and KSI, the emphasis is more on how the policy that will be carried out by the National Development Planning Agency also involves several partner institutions which have a strong research base (OGI, 2017; KSI, 2020). Meanwhile, by looking at the existing innovation patterns in National Research and Innovation Agency and by listening to the open science community, they are more about strengthening networks and resources in providing support for innovative policy making.

In the broader context, what is actually happening right now cannot be separated from dynamics on an international scale as well, especially in terms of knowledge and policy connection. National Development Planning Agency and KSI cannot be separated from the participation of the Australian government as the funding, whereas for the context of the Open Science Community, it has a network that tends to be informal in the open science community in various universities in the world (Open Science Framework).

In 2011, Indonesia together with several other countries in the world initiated the Open Government Partnership (OGP). Especially for Indonesia, this spirit besides being part of the value of openness is also a response to the rules of Public Information Openness, which then realized through a national initiative on Open Government in 
Vol.6, No.1, 2020

Doi: https://doi.org/10.24198/cosmogov.v6i1.25474

http://jurnal.unpad.ac.id/cosmogov/index

2010. Public Information Openness has the main reasoning that everything related to public affairs, be the right for the public to obtain related information. More practically, with regard to research and publications, research that is funded by the public must be accessible to the public.

OGP at the national scale is then implemented through Open Government Indonesia (OGI) which has the main goal for bureaucratic reform and government transparency. The manifestation of OGI itself is first, there is an escalation of transparency in the government institutions, especially related to the regulations and also the results of Research and Development. Second, educating the importance of data openness and encouraging the public to be actively involved in the spirit of openness. Although not exactly the same, what becomes the spirits of OGP and OGI are in line with what being done by the Open Science epistemic community.

The Open Data in Indonesia has been running for about a decade, yet it has not been running optimally, even as the initiator, Indonesia in 2016 only ranked 61 (GODI, 2016), below Singapore (17) and Thailand (51). Even though, Indonesia is one of eight countries that participated in the initiation of OGP. In addition, Indonesia is targeting national government information disclosure in 2025. So far, some of the identified challenges have been the process of publishing and testing the validity and the sustainability of data with the establishment of the Open Data ecosystem. This certainly becomes synchronous with the existence of the Open Science community which has the same vision to encourage openness and validation of competency-based research. Therefore, it means that the Open Data policy is very likely to be accelerated, with the opportunity that research-based policy will be better (World Bank, 2019).

Reflecting on the intense relationship between the National Development Planning Agency -KSI which is related to the formation of several policies, then the openness of science and its relevance to policy becomes urgent. In addition, the emergence of Open Science Community in 2017 and the National Research and Innovation Agency in 2019, makes this collaboration will truly be the main mover in relation to policy making on cross-sectoral and national-scale. The policy no longer relies on the role of one or two actors, but on their agreement, that research is the foundation of policy. Moreover, with the same idea approach, this will avoid the possibility of the Twin Sun', between the National Development Planning Agency and the National Research and Innovation Agency. Both will make the similarity of ideas as part of the consolidation of resources for the benefit of the nation.

By the presence of openness of science and data which is more accessible and not centralized in the state, then the interaction between civil society and the state becomes more egalitarian. Therefore, in the academic and policy studies shown up by the government, especially the National Development Planning Agency and National Research and Innovation Agency, then there are also ideas that originated from civil society. With a more equal interaction, it produces policy that has 
Vol.6, No.1, 2020

Doi: https://doi.org/10.24198/cosmogov.v6i1.25474

http://jurnal.unpad.ac.id/cosmogov/index

a stronger argumentation base and at the same time, its usefulness will be easier to be spread out. Because there are other actors who are also directly involved in the process and interact directly with the public or wider audience. The deliberation of knowledge as a derivative of democratic deliberation makes it possible that there is no one who has dominant in policy making, the most important is the presence or the absence of scientific arguments used.

\section{CONCLUSION}

Leadership is therefore not a matter of actors, but a matter that goes beyond that, that is the idea. Talking about leadership with an actor approach will give influence on a too strong focus on one role, while on the broader issues such as policybased research to the national interest, can be ignored. Consequently, the solidity of resources in the same idea actually becomes a more pressing issue. In addition, the collaboration in the form of common ideas becomes the basis of leadership on a larger scale and across the sectors.

Furthermore, the reading of civil society in the present context cannot only be seen as a form of organization. But, civil society also can be seen as a more fluid element, where the involvement of actors and ideas can emerge from various sources. They no longer have to be in a certain position with regard to the socio-political relations between the state and the non-

\section{REFERENCES}

Aribowo, Eric Kunto (2019), Perkembangan dan Penerapan Sains Terbuka di Indonesia. Retrieved from https://figshare.com/articles/Perke state. Moreover, it is possible that they are multi-role ideas that actually emerge in the state and non-state as well. Thus, civil society is a collection of slices of ideas and does not represent certain actors, especially something outside the state.

The context of partnership within the framework of the science openness movement for academics and policy can be seen from the relationship between the National Development Planning Agency, KSI, and the emergence of the Indonesian Open Science and the formation of the National Research and Innovation Agency. This provides a new opportunity in seeing research-based policy as a cross-sectoral collaboration. Collaboration based on the similarity of ideas becomes a proposal for new opportunity in reading civil society. Afterward, civil society is not merely an organization that leads by an actor such as an institution which all the time is imagined. However, through the leadership of ideas, civil society can also be seen as an epistemic community with the unity of the idea of science openness for academics and policy, across non-state institutions (KSI and Open Science Community), as well as the state (National Development Planning Agency and National Research and Innovation Agency). Where the elements in it work together between institutions and sectors for the same interests: Research-Based Policy.

mbangan_Penerapan_Sains_Terbu ka_di_Indonesia/9761207/1 17 March 2020

Asmad, C. C.; Mathar, T.; Akbar, A. K.; Arifin, N., Hijrana, H.; Haruddin, H.; Satriani, S. (2018). Tren 
Vol.6, No.1, 2020

Doi: https://doi.org/10.24198/cosmogov.v6i1.25474

http://jurnal.unpad.ac.id/cosmogov/index

Perkembangan Open Access Institutional Repository pada Perguruan Tinggi di Indonesia. Khizanah Al-Hikmah: Jurnal Ilmu Perpustakaan, Informasi, Dan Kearsipan, 6(2), 168-180.

Avolio, B. J., \& Gardner, W. L. (2005). Authentic leadership development: Getting to the root of positive forms of leadership. The Leadership Quarterly, 16(3), 315338.

Beland, D. (2009). Ideas, institutions, and policy change. Journal of European Public Policy, 16(5), 701-718.

Bennett, E., Coule, T., Damm, C., Dayson, C., Dean, J., \& Macmillan, R. (2019). Civil society strategy: a policy review. Voluntary Sector Review, 10(2), 213-223.

Bower, Joseph B.; Christensen, C. (1995). Disruptive Technologies: Cathing the Wave. Retrieved from https://hbr.org/1995/01/disruptivetechnologies-cathcing-the-wave

Brandsen, T., Trommel, W., \& Verschuere, B. (2017). The state and the reconstruction of civil society. International Review of Administrative Sciences, 83(4), 676-693.

Cohendet, P., Grandadam, D., Simon, L., \& Capdevila, I. (2014). Epistemic communities, localization and the dynamics of knowledge creation. Journal of Economic Geography, 14(5), 929-954. https://doi.org/10.1093/jeg/lbu018

Cosgrove, S. (2010). Leadership from the margins: Women and civil society organizations in Argentina, Chile, and El Salvador. Rutgers University Press.

Crevani, L., Lindgren, M., \& Packendorff, J. (2010). Leadership, not leaders: On the study of leadership as practices and interactions. Scandinavian Journal of Management, 26(1), 77-86.

De Tocqueville, A. (1982). Alexis de Tocqueville on democracy, revolution, and society. University of Chicago Press.
Dunlop, C. A. (2012). Epistemic communities. In Routledge Handbook of Public Policy (pp. 229-243). https://doi.org/10.4337/978178347 4684.00022

Gardner, W. L., Lowe, K. B., Meuser, J. D., Noghani, F., Gullifor, D. P., \& Cogliser, C. C. (2020). The leadership trilogy: A review of the third decade of the leadership quarterly. The Leadership Quarterly, 101379.

GODI. (2016). The GODI 2016/17 report: The State of Open Government Data in 2017. Insights.

Gurdjian, P., Halbeisen, T., \& Lane, K. (2014). Why leadershipdevelopment programs fail. McKinsey Quarterly, (1).

Habermas, J. (2010). The public sphere: an encyclopedia article (1964). The Idea of the Public Sphere: A Reader, 114-120.

Habermas, J., Lennox, S., \& Lennox, F. (1974). The public sphere: An encyclopedia article (1964). New German Critique, (3), 49-55.

Hohendahl, P. U., \& Silberman, M. (1979). Critical theory, public sphere and culture: Jürgen Habermas and his critics. New German Critique, 16(1), 89-118.

Irawan, D. E. (2017), Open science, good science. Retrieved from: http://dasaptaerwin.net/wp/2017/09 /open-science-good-science.html 17 March 2020.

Irawan, D. E. (2020), Jangan telantarkan sains anda: sains terbuka di Pusdatin Kemristek-BRIN. Retrieved from: http://dasaptaerwin.net/wp/2020/02 /jangan-terlantarkan-sains-andasains-terbuka-di-pusdatinkemristek-brin.html 15 March 2020.

Irawan, D. E., Rachmi, C. N., Irawan, H., Abraham, J., Kusno, K., Multazam, M. T., ... \& Aziz, N. A. (2017). Penerapan open science di Indonesia agar riset lebih terbuka, mudah diakses, dan meningkatkan dampak saintifik. Berkala Ilmu 
Vol.6, No.1, 2020

Doi: https://doi.org/10.24198/cosmogov.v6i1.25474

http://jurnal.unpad.ac.id/cosmogov/index

Perpustakaan dan Informasi,
13(1), 25-36.

Kemenristek. (2020). Rakornas Kemenristek/BRIN Tahun 2020 di Puspitek dibuka oleh Presiden Republik Indonesia.

Keohane, N. O. (2014). Civil Society and Good Democratic Leadership. In Good Democratic Leadership (pp. 70-89).

https://doi.org/10.1093/acprof:oso/ 9780199683840.003.0005

Kindon, S., Pain, R., \& Kesby, M. (2007). Participatory action research approaches and methods: Connecting people, participation and place (Vol. 22). Routledge.

Kiramang, Khaeruddin (2019), Sains Tebuka. Retreived from: https://www.sbs.com.au/language/i ndonesian/audio/sains-terbuka 18 March 2020

Klein, S., \& Lee, C.-S. (2019). Towards a dynamic theory of civil society: The politics of forward and backward infiltration. Sociological Theory, 37(1), 62-88.

Knouse, S. B., \& Carson, K. D. (1993). W. Edwards Deming and Frederick Winslow Taylor: A comparison of two leaders who shaped the world's view of management. International Journal of Public Administration, 16(10), 16211658.

Knowledge Sector Initiative. (2020). Publikasi KSI. Retrieved from https://www.ksi-

indonesia.org/en/knowledge/public ations/24 17 March 2020.

Knowledge Sector Initiative (2020), About KSI. Retrieved from: https://www.ksiindonesia.org/old/en/pages/aboutksi 16 March 2020

Knowledge Sector Initiative (2020), Working Papers. Retieved from: https://www.ksiindonesia.org/old/en/news/index/w orking-papers 16 March 2020

Krawczyk, K. A. (2019). International NGOs, Transnational Civil Society, and Global Public Policy. In The Oxford Handbook of
Global Policy and Transnational Administration (pp. 147-164). https://doi.org/10.1093/oxfordhb/9 780198758648.013.16

Margetts, H. Z., John, P., Hale, S. A., \& Reissfelder, S. (2015). Leadership without leaders? Starters and followers in online collective action. Political Studies, 63(2), 278-299.

Mayntz, R. (2017). From government to governance: Political steering in modern societies. In Governance of Integrated Product Policy. Routledge, 18-25.

Meyer, M., \& Molyneux-Hodgson, S. (2010). Introduction: The Dynamics of Epistemic Communities. Sociological Research Online, 15(2), 109-115. https://doi.org/10.5153/sro.2154

Open Goverment Indonesia (2017), Menjembatani pengetahuan dengan kebijakan publik: Wawancara dengan Team Leader Knowledge Sector Initiative. Retrieved from: http://ogi.bappenas.go.id/news/244 /menjembatani-pengetahuandengan-kebijakan-publikwawancara-dengan-team-leaderknowledge-sector-initiative $\quad 16$ March 2020

Overseas Development Institute (2017), Australia-Indonesia Partnership for Pro-Poor Policy: the Knowledge Sector Initiative. Retrieved from: https://www.odi.org/projects/2677australia-indonesia-partnershippro-poor-policy-knowledge-sectorinitiative 15 March 2020

Pellini, A., Prasetiamartati, B., Nugroho, K. P., Jackson, E., \& Carden, F. (2018). Knowledge, politics and policymaking in Indonesia. Knowledge, Politics and Policymaking in Indonesia. https://doi.org/10.1007/978-98113-0167-4

Prasetyo, A. G. (2012). Menuju Demokrasi Rasional: Melacak Pemikiran Jürgen Habermas tentang Ruang Publik. Jurnal Ilmu Sosial Dan Ilmu Politik, 16(2), 169-185. 
Vol.6, No.1, 2020

Doi: https://doi.org/10.24198/cosmogov.v6i1.25474

http://jurnal.unpad.ac.id/cosmogov/index

Puskapol UI. (2014). FISIP Universitas Indonesia (PUSKAPOL FISIP UI). Analisis Perolehan Suara Dalam Pemilu.

Raelin, J. A. (2016). Imagine there are no leaders: Reframing leadership as collaborative agency. Leadership, 12(2), 131-158.

Rhodes, R. A. W. (1996). The new governance: governing without government. Political Studies, 44(4), 652-667.

Ridlo, Ilhan Akhsanu (2018), Zaman Sains Terbuka. Retrieve from: https://fkm.unair.ac.id/zamansains-terbuka/ 19 March 2020

RistekBRIN. (2020). Panduan Editor Jurnal Ilmiah.

Ritchie, J., Lewis, J., Nicholls, C. M., \& Ormston, R. (2013). Qualitative research practice: A guide for social science students and researchers. sage.

Rosenberg, L. R. (2010). Transforming leadership: Reflective practice and the enhancement of happiness. Reflective Practice, 11(1), 9-18. https://doi.org/10.1080/146239409 03525207

Sains Terbuka (2019), Tweet about Sains Terbuka. Twitter on 4 July 2019

Sutherland, N. (2013). Leadership without leaders? Paper Presented at International Conference in Critical Management Studies.

Taylor, F. W. (2004). Scientific management. Routledge.

World Bank. (2019). Big data \& the public sector: Resource blessing or curse?

The Conversation (2019), Analysis: Indonesian policymaking is not supported by quality research and academic freedom. Retrieved from:

https://theconversation.com/analysi s-indonesian-policymaking-is-notsupported-by-quality-research-andacademic-freedom-126023 16 March 2020.

The Conversation (2020), Sains Terbuka, mengapa penting bagi Indonesia yang dana risetnya kecil. Retrieved from:

https://theconversation.com/sainsterbuka-mengapa-penting-bagiindonesia-yang-dana-risetnyakecil-111069 18 March 2020

Tim Sains Terbuka (2020), Startegi Sains Terbuka. Retreived from: https://sainsterbuka.carrd.co 19 March 2020

van Dierendonck, D. (2011). Servant leadership: A review and synthesis. Journal of Management. https://doi.org/10.1177/014920631 0380462

Wang, J. (2018). Book review: Holistic leadership: A new paradigm for today's leaders. SAGE Publications Sage UK: London, England.

Webinar Sains (2019), Advancing Science in Indonesia: Current Global Research Practice. Retrieved from: https://www.webinarsains2019.co m 16 March 2020

\section{ACKNOWLEDGEMENT}

The research for this article was funded through the scheme of IMPACT scholarship in the Doctoral Program in Leadership and Policy Innovations at Universitas Gadjah Mada 2018-2021. Author would like to thanks to Dyah Prabaningrum who helped in language correction of this manuscript and the anonymous reviewers for their inputs and corrections. 